\title{
Pendampingan Masyarakat Bantaran Sungai dalam Pendirian Bank Sampah untuk Meminimalisir Sampah Sungai di Kelurahan Pegirian Kota Surabaya
}

\author{
Khuliyah Candraning Diyanah ${ }^{1)}$, Aditya Sukma Pawitra 2), Ni Luh Putu Arum \\ Puspitaning Ati ${ }^{3)}$, Mohammad Bastian'), Ika Septyaningsih'), Rahmat Adi Prasetyo( \\ 1,2) Departemen Kesehatan Lingkungan, Fakultas Kesehatan Masyarakat, Universitas Airlangga, \\ Surabaya \\ 3)Kementerian Desa, Pembangunan Daerah Tertinggal, dan Transmigrasi \\ 4)RSUD dr Saiful Anwar Malang \\ 5)Puskesmas Ponggok Kabupaten Blitar \\ 6) S1 Kesehatan Masyarakat Minat Administrasi dan Kebijakan Kesehatan, Fakultas Kesehatan \\ Masyarakat, Universitas Airlangga, Surabaya \\ k.c.diyanah@fkm.unair.ac.id; aditya.pawitra@fkm.unair.ac.id; putuarum@gmail.com; \\ bastian.mohammad@gmail.com; ika.septya17@gmail.com; adi.alkhidmah@gmail.com
}

\begin{abstract}
Pegirian village is one of the riverbanks areas which is located in semampir district, Surabaya. This village has no trash to collect garbage generated by the community, so most of it is littered in the river. The empowerment program is referring to the Dignan theory by analyzing the problem, assessment targets, program developments, implementation, and evaluation. This activity implements in hamlet (RW)04/neighbourbood (RT) 09 of pegirian. The result of analyzing a problem, priority problems and alternative solutions found that the community does not have garbage so that they disposed of waste at the river. Therefore it is necessary to initiate the establishment of waste banks. The garbage bank program invites people to save their waste by holding the 3R principle (Reduce, Reuse, Recycle). The purpose of this garbage bank program is to empower the community to manage its waste through the garbage bank and get additional income. Assistance for the initiation of the establishment of a garbage bank in pegirian village succeeded in moving the community to become a member of total family heads that exist in the region RW 04/RT 09 of pegirian village. Besides, they have an increase in capacity of $78 \%$ (from the results of the post-test) and knowledge in knowing and knowing the governance of waste banks.
\end{abstract}

Keyword: Community along the River, Community Empowerment, Dignan theory, Waste Bank.

\begin{tabular}{|c|c|c|c|c|}
\hline Received & May 9th 2019 & Revised & Sept $10^{\text {th }} 2019$ & Nov $2^{\text {th }} 2019$ \\
\hline
\end{tabular}

\section{Pendahuluan}

Perilaku membuang sampah di sungai (Baca bahasa Jawa: kali) masih banyak dilakukan oleh masyarakat Jawa Timur termasuk di Kota Surabaya. Pemerintah Kota Surabaya sangat berkomitmen dalam menjaga kualitas lingkungan termasuk dalam pengelolaan sampah. Jumlah sampah di Surabaya yang masuk ke Tempat Pembuangan Akhir (TPA) Benowo adalah 1.600 ton setiap hari. Padahal jumlah penduduk sebanyak 3,07 juta jiwa. Dengan jumlah penduduk sebesar itu, semestinya jumlah sampah berdasarkan rasio mencapai 2.600 ton per hari. Sebanyak 1.000 ton sampah yang tersisa, semestinya sudah direduksi di masyarakat atau tempat usaha.

Di Surabaya sudah cukup banyak terdapat pegiat lingkungan yang kemudian mendirikan bank sampah sebagai solusi dalam pengurangan sampah anorganik baik yang diinisiasi oleh 


\section{ENGAGEMENT}

Lurnal Pengabdian Kepada Masyarakat

ISSN : 2579-8375 (Print)

ISSN : 2579-8391 (Online)
This work is licensed under a Creative Commons Attribution-ShareAlike 4.0 International License.

Pemerintah Kota (Pemkot) maupun inisiatif warga, akan tetapi masih ada kawasan Surabaya Barat, Utara, dan Timur yang belum sepenuhnya terjangkau kebersihannya oleh Pemerintah Kota Surabaya dan warga belum tergerak dalam upaya pengurangan sampah. Masih ada titik-titik tertentu yang menjadi area warga membuang sampah, terutama di kali dan jembatan ${ }^{1}$, salah satunya di Kelurahan Pegirian.

Kelurahan Pegirian yang terletak di kawasan Surabaya Utara, merupakan salah satu daerah yang terletak di area bantaran sungai, wilayah Kecamatan Semampir, Kota Surabaya, Propinsi Jawa Timur dengan luas wilayah $0,40 \mathrm{~km}^{2}$ dan jumlah penduduk 31.904 jiwa. Kelurahan Pegirian yang mempunyai kepadatan penduduk 79.760 jiwa $/ \mathrm{km}^{2}$ mempunyai rata-rata timbulan sampah sebesar 15,956 ton setiap harinya. Permasalahan sampah ini menjadi perhatian yang sangat serius. Selain berdampak di lingkungan, masalah sampah juga berdampak pada kesehatan masyarakat. Di Kelurahan Pegirian ini, penyakit sistem pencernaan seperti diare merupakan penyakit terbanyak nomer dua ${ }^{2}$. Kesadaran masyarakat akan pentingnya pengolahan sampah masih rendah sehingga diperlukan berbagai upaya, baik dari Pemerintah Kota, Perguruan Tinggi, maupun masyarakat sendiri.

Kurangnya kesadaran masyarakat dalam membuang sampah pada tempatnya akan berakibat pada kurangnya partisipasi masyarakat dalam menjaga lingkungan. Kurangnya partisipasi masyarakat untuk mengikuti kegiatan bersama membersihkan lingkungan mengakibatkan sampah yang ada belum tertangani dengan baik $^{3}$. Salah satu upaya Pemerintah Kota dalam upaya mereduksi sampah yang juga melibatkan partisipasi masyarakat, adalah dengan mendirikan bank sampah yang melibatkan warga masyarakat. Hal ini juga yang menjadi perhatian bagi Perguruan Tinggi dengan melaksanakan pemberdayaan kepada masyarakat. Dalam upaya mendukung pelaksanaan bank sampah di masyarakat, pemerintah telah mengeluarkan Peraturan Menteri Negara Lingkungan Hidup Nomor 13 Tahun 2012 tentang Pedoman Pelaksanaan reduce, reuse, dan recycle melalui Bank Sampah ${ }^{4}$. Pada Peraturan ini, telah dicantumkan: (1) persyaratan bank sampah; (2) mekanisme kerja

1 BBC News Indonesia, "Ke Mana Perginya 1.000 Ton Sampah Di Surabaya?," last modified 2018, accessed November 1, 2019, https://www.bbc.com/indonesia/majalah-43939576.

2 BPS Kota Surabaya, Kecamatan Semampir Dalam Angka 2018 (Surabaya, 2018), https:// surabayakota.bps.go.id/publication/2018/09/26/90ec03cb6809df424f7e6ee8/kecamatan-semampir-dalamangka-2018.html.

${ }^{3}$ Nurul Purbasari, "Pemberdayaan Masyarakat Melalui Kegiatan Daur Ulang Sampah Plastik (Studi Kasus Pada Komunitas Bank Sampah Poklili Perumahan Griya Lembah Depok Kecamatan Sukmajaya Kota Depok)" (UIN Syarif Hidayatullah Jakarta, 2014).

${ }^{4}$ Menteri Lingkungan Hidup, Peraturan Menteri Lingkungan Hidup No 13 Tabun 2012 Tentang Pedoman Pelaksanaan Reduce, Reuse Dan Recycle Melalui Bank Sampab (Jakarta, 2012), accessed November 1, 2019, http://sipsn.menlhk.go.id/?q=content/peraturan-menteri-lh-no-13-tahun-2012.

Volume 3, Number 2, November 2019| 246

Pendampingan Masyarakat Bantaran Sungai dalam Pendirian Bank Sampah untuk Meminimalisir Sampah Sungai di Kelurahan Pegirian Kota Surabaya 
bank sampah; (3) pelaksanaan bank sampah; dan (4) pelaksana bank sampah.

Berdasarkan hasil analisis situasi, Kelurahan Pegirian memiliki beberapa aspek dalam hal kekuatan (strength), kelemahan (weakness), ancaman (threats) dan peluang (opportunity). Kader PKK (Pemberdayaan Kesejahteraan Keluarga) dan karang taruna di kelurahan ini aktif berpartisipasi pada kegiatan lingkungan, serta adanya dukungan dari Lurah Pegirian terhadap kegiatan sosial menjadi kekuatan yang dimiliki oleh Kelurahan ini. Kekurangan yang dimiliki kelurahan mitra adalah kurangnya tempat pengumpulan sampah dan letak penampungan sampah sementara yang di bibir sungai, sehingga warga kesulitan membuang sampah di tempat yang benar dan langsung dilemparkan ke area sungai/kali. Sungai ini meskipun tidak dapat lagi dimanfaatkan sebagai sumber air bersih, sampah yang terdapat di sungai membuat estetika menurun dan menimbulkan bau yang tidak sedap, dan bila musim hujan sampah tersebut menghambat aliran air sungai sehingga air mudah meluber ke badan jalan. Jika dilihat dari karakteristik masyarakat, sebagian besar berpendidikan rendah sehingga penduduk memilih bekerja sebagai pedagang, buruh atau pekerja lepas, yaitu jenis pekerjaan yang tidak berorientasi pada tingkat pendidikan.

Sementara itu, dilihat dari faktor eksternal kelurahan Pegirian ini juga memiliki ancaman, sulitnya menemukan tempat untuk menyimpan sampah yang telah ditabung masyarakat. Oleh karena itu, diperlukan bantuan perijinan dari pemerintah untuk dapat membangun bank sampah di area Kelurahan Pegirian. Sedangkan dilihat dari peluang atau kesempatan, yaitu mampu membantu kelurahan menjadi daerah Merdeka dari Sampah.

Berdasarkan analisis tersebut, dapat ditarik akar permasalahan pada kelurahan mitra yaitu belum adanya informasi yang diterima masyarakat terkait cara pengelolaan sampah agar menjadi bernilai ekonomis. Penumpukan sampah di lingkungan kelurahan perlu diatasi dengan program pengelolaan sampah yang tersistem sekaligus menambah pemasukan baru bagi masyarakat. Mengingat tingginya partisipasi masyarakat dalam kegiatan di daerahnya, maka program pemberdayaan dapat menjadi alternatif solusi terhadap permasalahan di Kelurahan Pegirian.

Oleh karena itu, Program Kemitraan Masyarakat (PKM) yang ditawarkan adalah dengan mendirikan bank sampah sebagai sentra pengelolaan sampah. Program tersebut ditawarkan dengan melihat permasalahan kelurahan mitra yaitu Kelurahan Pegirian, Kecamatan Semampir, Kota Surabaya. Bank sampah merupakan tempat pemilahan dan pengumpulan sampah yang dapat didaur ulang dan/atau diguna ulang yang memiliki nilai ekonomi. Penerapan program bank sampah di Kelurahan Pegirian dapat menjadi strategi untuk maningkatkan kepedulian masyarakat agar dapat "berkawan" dengan sampah karena memperoleh manfaat ekonomis dari sampah. Dengan menerapkan prinsip 3R (Reduce, Reuse, Recycle), bank sampah dapat menjadi solusi agar penyelesaian 
masalah sampah tidak hanya berfokus pada petugas kebersihan saja melainkan melibatkan partisipasi aktif masyarakat.

\section{Metode}

Metode yang digunakan dalam program ini mengacu pada kerangka kerja Teori Dignan yang merupakan teori mengenai pemberdayaan masyarakat dimana kita harus menentukan komunitas sasaran untuk mengembangkan suatu program sehingga program tersebut dapat berjalan sesuai dengan harapan. Tahapan dalam setiap upaya pemberdayaan menurut ${ }^{567}$, melalui langkah-langkah sebagai berikut :

1. Analisis masalah (community analysis), yaitu dengan menganalisis keadaan atau kondisi yang ada pada masyarakat meliputi analisis pendidikan, perkerjaan, umur, keadaan geografis, dan lain sebagainya. Data ini merupakan data sekunder yang didapat dari kantor Kelurahan Pegirian dan juga dari data BPS Kota Surabaya. Juga data primer dari hasil wawancara terhadap Tokoh Masyarakat dan observasi lingkungan yang dilakukan oleh fasilitator.

2. Penilaian target (targeted assessment), dilakukan dengan memperhatikan jumlah sasaran yang akan diintervensi, lokasi strategis dari kegiatan yang akan dilakukan, jenis kelamin sasaran, kualitas sumber daya yang dimiliki, pekerjaan, dan pendidikan, serta perubahan perilaku yang diinginkan. Kegiatan yang dilakukan dalam proses penilaian target adalah menentukan prioritas masalah dengan metode urgency, seriousness, dan growth (USG), serta penentuan alternatif solusi dengan metode capability, accesibility, readiness, leverage (CARL). Yang dilibatkan dalam penilaian target ini adalah tokoh masyarakat, warga, PKK, dan Karang Taruna.

3. Pengembangan program (program plan development), merupakan tahap perencanaan program yang dilakukan secara spesifik mengenai lokasi kegiatan, alat dan bahan yang digunakan, rencana implementasi program yang akan dilaksanakan dengan memperhatikan dasar model perubahan perilaku. Dalam tahapan ini dibuat Rencana Usulan Kegiatan (RUK) yang merupakan teknik penulisan kegiatan lanjutan dari yang telah dilakukan beberapa tahun ke

\footnotetext{
${ }^{5}$ I Yuliandari, Inriza, Nenda Puspita Sari, Rochmad Ardiansyah, and Novanyanti Nur. "Angon Sampah Sebagai Upaya Pemberdayaan Masyarakat Berbasis Potensi Lokal Di Desa Pesucen Melalui Teori Dignan.” Promotif: Jurnal Kesehatan Masyarakat 8, no. 2 (2018): 112-122.

${ }^{6}$ Ardi Bastian, "Perencanaan Program Promosi Kesehatan dalam Penanggulangan HIV dan AIDS pada Ibu Rumah Tangga di Kota Kediri Menggunakan Kerangka Teori Dignan dan Carr” (Universitas Airlangga, 2017).

7 MB Dignan and PA Carr, Program Planning for Health Education and Promotion, 2nd Ed. (Philadelphia: Lea \& Febiger, 1992).
} 


\section{ENGAGEMENT}

Lurnal Pengabdian Kepada Masyarakat

ISSN : 2579-8375 (Print)

ISSN : 2579-8391 (Online)
This work is licensed under a Creative Commons

Attribution-ShareAlike 4.0 International License.

CC BY SA

depan dengan suatu konsep tertentu setelah melakukan analisis, menetapkan prioritas masalah, merumuskan masalah, dan menetapkan alternative solusi.

4. Implementasi (implementation), merupakan sebuah elemen yang berbentuk tindakan dan dilakukan agar dapat mencapai tujuan sesuai yang sudah ditetapkan. Implementasi dapat dipengaruhi oleh perilaku dan pengetahuan setiap individu. Secara tidak langsung implementasi juga dapat dipengaruhi oleh keadaan lingkungan sekitar. Apabila ketiga faktor tersebut mempunyai kualitas yang baik, maka individu tersebut dapat menerapkan atau mengimplementasikannya dengan baik pula

5. Evalusai (evaluation) yang meliputi evaluasi proses dan evaluasi hasil. Evaluasi proses yaitu berjalannya kegiatan dengan baik, tepat waktu dan lancar sesuai dengan RUK yang telah ditetapkan, serta masyarakat aktif mengikuti kegiatan. Sedangkan evaluasi hasil yaitu dengan melihat antusiasme masyarakat dalam mengikuti kegiatan, serta meningkatnya pengetahuan masyarakat akan pentingnya pengelolaan sampah.

Secara rinci tahapan tersebut digambarkan dalam skema berikut.

\begin{tabular}{|c|l|l|l|}
\hline $\begin{array}{l}\text { Analisis masalah yang meliputi } \\
\text { analisis pendidikan, perkerjaan, } \\
\text { umur, keadaan geografis, dll }\end{array}$ & $\begin{array}{l}\text { Penilaian target } \\
\text { dengan metode } \\
\text { USG, dan CARL }\end{array}$ \\
$\qquad \begin{array}{l}\text { Evaluasi proses (kegiatan berjalan dengan baik } \\
\text { sesuai RUK), serta evaluasi hasil (antusiasme } \\
\text { masyarakat, dan meningkatnya pengetahuan } \\
\text { masyarakat) }\end{array}$ & $\begin{array}{l}\text { Pengembangan program } \\
\text { melalui Rencana Usulan } \\
\text { Kegitan (RUK) }\end{array}$ \\
\hline
\end{tabular}

\section{Gambar 1. Skema Perencanaan Kegiatan dalam Kerangka Teori Dignan}

\section{Hasil dan Pembahasan}

Bank sampah yang akhirnya muncul sebagai alternatif pemecahan masalah lingkungan di Kelurahan Pegirian, khusunya di wilayah RW 04/RT 09 merupakan salah satu program pemberdayaan masyarakat yang dimaksudkan untuk menumbuhkan kesadaran dan kemandirian masyarakat dalam mengelola sampah agar selanjutnya masyarakat dapat hidup dengan lebih baik melalui upaya pemanfaatan berbagai potensi yang ada, serta uapaya memperbaiki kualitas lingkungan. ${ }^{8}$ Pemberdayaan masyarakat melalui program Bank Sampah juga dimaksudkan untuk

8 Amang Fathurrohman et al., "Implementasi Manajemen Bank Sampah IT Pada Komunitas Bank Sampah 


\section{ENGAGEMENT}

Lurnal Pengabdian Kepada Masyarakat

ISSN : 2579-8375 (Print)

ISSN : 2579-8391 (Online)
This work is licensed under a Creative Commons Attribution-ShareAlike 4.0 International License.

CC BY SA

memberi kontribusi bagi pembangunan ekonomi di suatu wilayah ${ }^{9}$. Perencanaan dan pelaksanaan program Bank Sampah di Kelurahan Pegirian ini didasarkan pada kerangka Teori Dignan, sehingga alternatif pemecahan masalah sesuai dengan keadaan masyarakat dan sesuai dengan nilai yang dianut masyarakat.

\section{Analisis Masalah (Community Analysis)}

Kelurahan Pegirian berada di Kecamatan Semampir, Kota Surabaya, Propinsi Jawa Timur. Kecamatan Semampir merupakan wilayah Surabaya Utara, dengan luas wilayah $6,65 \mathrm{~m}^{2}$ yang berbatasan dengan selat Madura di sebelah utara, Kecamatan Kenjeran di sebelah timur, Kecamatan Simokerto di sebelah selatan, dan Kecamatan Pabean Cantika di sebelah barat. Kondisi geografi di wilayah Kelurahan Pegirian memiliki topografi rendah dengan ketinggian tanah 4,6 meter dari permukaan laut. Luas wilayah Kelurahan Pegirian sendiri adalah $0,40 \mathrm{~km}^{2}$ dengan jumlah penduduk 31.904 jiwa dan kepadatan penduduk 79.760 jiwa $/ \mathrm{Km}^{2}$. Jumlah keluarga di Kelurahan

Pegirian adalah 6.284, dengan rata-rata anggota keluarga berjumlah 5 orang $^{10}$. Penduduk yang terlalu padat menjadi penyebab timbulnya berbagai masalah kependudukan dan ketenagakerjaan, yaitu tingkat pendidikan yang rendah dan tingkat pengangguran yang semakin naik. Padatnya penduduk menyebabkan semakin besar pula jumlah pencari kerja dibandingkan dengan lapangan kerja yang ada, sehingga jumlah pengangguran meningkat. Hal ini berdampak pada menurunnya kualitas sosial, seperti banyaknya tuna wisma, pengemis, kriminalitas, dan lain-lain ${ }^{11}$.

Tingkat pendidikan masyarakat Kelurahan Pegirian masih terbilang cukup rendah, dimana sebanyak 19\% dari penduduk Kelurahan Pegirian masih berpendidikan SD. Penduduk yang berpendidikan SLTP sebesar 15,7\% dan SLTA sebesar 26\%. Namun sebanyak 10\% dari penduduk Kelurahan Pegirian memilih keluar dari sekolah. Sisanya yaitu 3,8\% penduduk telah mampu mengenyam pendidikan sampai perguruan tinggi ${ }^{12}$. Lebih dari $50 \%$ masyarakat khusunya RW 04/RT 09 Kelurahan Pegirian memiliki tingkat pendidikan setara dengan SD atau bahkan lebih

Berbasis Masyarakat, Pemuda, Dan Sekolah Di Kabupaten Pasuruan," Engagement: Jurnal Pengabdian Kepada Masyarakat 2, no. 2 (2018): 154-167, http://engagement.fkdp.or.id/index.php/engagement/article/view/35.

9 Yuliandari, Inriza, Nenda Puspita Sari, Rochmad Ardiansyah, and Novanyanti Nur. "Angon Sampah Sebagai Upaya Pemberdayaan Masyarakat Berbasis Potensi Lokal Di Desa Pesucen Melalui Teori Dignan.” Promotif: Jurnal Kesehatan Masyarakat 8, no. 2 (2018): 112-122.

10 BPS Kota Surabaya, Kecamatan Semampir Dalam Angka 2018.

11 Charis Christiani, Pratiwi Tedjo, and Bambang Martono, "Analisis Dampak Kepadatan Penduduk Terhadap Kualitas Hidup Masyarakat Provinsi Jawa Tengah,” Serat Acitya 3, no. 1 (2014): 102.

${ }^{12 B P S}$ Kota Surabaya, Kecamatan Semampir Dalam Angka 2016 (Kota Surabaya, 2016), https://surabayakota.bps.go.id/publication/2016/07/29/441878badba3c8525b717c0d/kecamatan-semampirdalam-angka-2016.

Volume 3, Number 2, November 2019| 250

Pendampingan Masyarakat Bantaran Sungai dalam Pendirian Bank Sampah untuk Meminimalisir Sampah Sungai di Kelurahan Pegirian Kota Surabaya 


\section{ENGAGEMENT}

Lurnal Pengabdian Kepada Masyarakat

ISSN : 2579-8375 (Print)

ISSN : 2579-8391 (Online)
This work is licensed under a Creative Commons Attribution-ShareAlike 4.0 International License. CC BY SA

rendah. Dengan banyaknya penduduk dengan tingkat pendidikan yang rendah, sehingga sebagian besar penduduk memilih bekerja sebagai pedagang. Selain sebagai pedagang, mereka bekerja sebagai buruh atau pekerja lepas, yaitu jenis pekerjaan yang tidak berorientasi pada tingkat pendidikan ${ }^{13}$.

Kelurahan Pegirian terdiri dari 11 RW dengan jumlah pengurus RW sebanyak 44 orang dan 96 RT dengan jumlah pengurus sebanyak 285 orang. Di Kelurahan Pegirian juga terdapat kader pembangunan kelurahan sebanyak 2 orang. Terdapat pula kader lain yaitu kader PKK diman jumlah tim penggerak PKK sebanyak 31 orang dengan jumlah kader sebanyak 505 orang $^{14}$. Warga Kelurahan Pegirian memiliki semangat yang luar biasa terkait kegiatan kelurahan. Hal tersebut dibuktikan dengan masih aktifnya Karang Taruna dan PKK (Pembinaan Kesejahteraan Keluarga) dalam mendukung segala kegiatan yang dapat memajukan Kelurahan Pegirian.

Berdasarkan segi kesehatan dan lingkungan permasalahan di Kelurahan Pegirian terletak pada pembuangan sampah yang belum baik dan teratur. Rata-rata timbulan sampah yang dihasilkan adalah sebesar 15,956 ton setiap harinya. Beberapa warga Kelurahan Pegirian membuang sampah pada area bantaran sungai/kali, sebagai akses terdekat dari tempat tinggal penduduk. Pemerintah hanya menyediakan tempat pembuangan sementara dengan kapasitas yang tidak mencukupi sampah seluruh warga dan terletak di pinggir sungai, sehingga bila bak penampungan sampah sementara terlalu penuh, sampah akan dengan mudah masuk ke sungai, dan warga pun dengan mudah melemparkan sampahnya ke sungai.

Sampah yang dibuang dan dihasilkan oleh warga Kelurahan Pegirian paling banyak adalah sampah anorganik seperti bekas botol minuman, sampah bungkus makanan, sampah bekas kardus botol minuman, yang merupakan sampah yang sulit terurai. Jika tidak ada tindak lanjut dari pembuangan sampah ini, maka akan berdampak dari segi estetika dan menyebabkan pencemaran terhadap tanah. Dampak terhadap estetika muncul karena sampah yang berserakan dan menumpuk menjadi kurang enak untuk dipandang oleh mata dan menimbulkan bau tidak sedap yang dapat mengganggu keseharian warga Kelurahan Pegirian. Sedangkan, dampak pencemaran tanah muncul akibat sulit terurainya sampah anorganik ketika berada di dalam tanah. Sampah anorganik yang sulit terurai dalam tanah dapat mengurangi kesuburan tanah itu sendiri. Sehingga, kualitas tanah akan mengalami penurunan. Sampah yang menumpuk juga dapat menjadi masalah bagi

${ }^{13}$ Nuria Nuria and Yuly Sulistyorini, “Analisis Kesehatan Masyarakat Berdasarkan Ruang Lingkup Kependudukan dan Ketenagakerjaan di Kelurahan Pegirian Kecamatan Semampir Kota Surabaya," Jurnal Biometrika dan Kependudukan 7, no. 2 (2019): 131-140.

14 BPS Kota Surabaya, Kecamatan Semampir Dalam Angka 2018.

Volume 3, Number 2, November 2019| 251

Pendampingan Masyarakat Bantaran Sungai dalam Pendirian Bank Sampah untuk Meminimalisir Sampah Sungai di Kelurahan Pegirian Kota Surabaya 


\section{ENGAGEMENT}

Lurnal Pengabdian Kepada Masyarakat

ISSN : 2579-8375 (Print)

ISSN : 2579-8391 (Online)
This work is licensed under a Creative Commons

Attribution-ShareAlike 4.0 International License.

CC BY SA

kesehatan ${ }^{15}$. Hal tersebut dikarenakan sampah yang menumpuk akan disenangi dan digunakan sebagai tempat tinggal vektor penyakit seperti lalat dan tikus. Sehingga, nantinya akan menimbulkan beberapa penyakit akibat vektor penyakit seperti diare dan leptospirosis. Di Kelurahan Pegirian ini, penyakit sistem pencernaan seperti diare merupakan penyakit terbanyak nomer dua ${ }^{16}$.
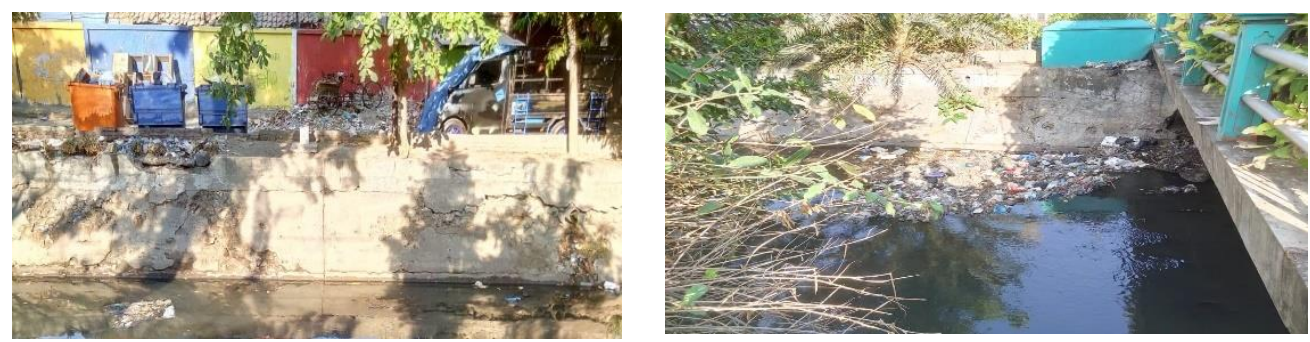

Gambar 2. Kondisi Tempat Penampungan Sampah Sementara dan Sungai di Kelurahan Pegirian

\section{Penilaian Target (Targeted Assessment)}

Setelah dilakukan analisis masalah, selanjutnya adalah dengan penilaian sasaran secara spesifik yang akan diintervensi melalui program pemberdayaan ini. Penilaian sasaran dilakukan dengan memperhatikan jumlah sasaran yang akan diintervensi, lokasi strategis dari kegiatan yang akan dilakukan, jenis kelamin sasaran, kualitas sumber daya yang dimiliki, pekerjaan, dan pendidikan, serta perubahan perilaku yang diinginkan. Penilaian target bersifat lebih subyeksional jika dibandingkan dengan analisis masalah yang masih memahami masalah secara global ${ }^{17}$.

Berdasarkan analisis masalah sebelumnya, didapatkan permasalahan di wilayah RW 04/RT 09 Kelurahan Pegirian ini adalah pendidikan masyarakat yang rendah, pekerjaan penduduk sebagian besar merupakan jenis pekerjaan yang tidak berorientasi pada tingkat pendidikan seperti buruh serabutan yang penghasilannya tidak tetap, tidak adanya tempat pengumpulan sampah sehingga warga kesulitan membuang sampahnya di tempat yang benar dan langsung dilemparkan ke area sungai/kali, angka kejadian penyakit pencernaan seperti diare masih tinggi. Masalah tersebut saling terkait satu sama lain, akan tetapi masalah yang secara langsung dapat ditangani oleh masyarakat adalah permasalahan sampah dan kasus diare. Diharapkan alternative solusi yang didaptkan dapat mengakomodir semua permasalahan yang ada.

15 Muslimah Muslimah Muslimah, "Dampak Pencemaran Tanah dan Langkah Pencegahan," Jurnal Penelitian Agrisamudra 2, No. 1 (2015): 11-20.

16 BPS Kota Surabaya, Kecamatan Semampir Dalam Angka 2018.

17 Dignan and Carr, Program Planning for Health Education and Promotion, 2nd Ed.

Volume 3, Number 2, November 2019| 252

Pendampingan Masyarakat Bantaran Sungai dalam Pendirian Bank Sampah untuk Meminimalisir Sampah Sungai di Kelurahan Pegirian Kota Surabaya 


\section{ENGAGEMENT}

Lurnal Pengabdian Kepada Masyarakat

ISSN : 2579-8375 (Print)

ISSN : 2579-8391 (Online)
This work is licensed under a Creative Commons Attribution-ShareAlike 4.0 International License.

CC BY SA

Untuk menentukan prioritas masalah yang ada, dilakukan penentuan prioritas dengan metode skoring USG (urgency, seriousness, growth) yang dilakukan oleh perwakilan warga, PKK dan karang taruna. Berikut adalah tabel hasil penentuan prioritas masalah di RW 04/RT 09 Kelurahan Pegirian.

Tabel 1. Prioritas Masalah dengan USG

\begin{tabular}{lcccc}
\multicolumn{1}{c}{ Masalah } & Urgency & Seriousness & Growth & Total \\
\hline $\begin{array}{l}\text { Tidak adanya tempat pengumpulan dan } \\
\text { pengolahan sampah }\end{array}$ & $\mathbf{5}$ & 4 & $\mathbf{5}$ & $\mathbf{1 4}$ \\
\hline Kasus diare masih tinggi & 4 & 3 & 4 & 11 \\
\hline
\end{tabular}

Setelah terpilih prioritas masalah, yaitu tidak adanya tempat pengumpulan dan pengolahan sampah, tahap selanjutnya adalah alternative solusi yang ditawarkan untuk mengatasi masalah tersebut. Penetuan alternatif pemecahan masalah menggunakan metode CARL (capability, accesibility, readiness, leverage). Berikut tabel penentuan alternatif pemecahan masalah.

Tabel 2. Alternatif Pemecahan Masalah dengan CARL

\begin{tabular}{lccccc}
\hline \multicolumn{1}{c}{ MASALAH } & Capability & Accesibility & Readiness & Leverage & TOTAL \\
\hline $\begin{array}{l}\text { Pendirian Bank } \\
\text { Sampah }\end{array}$ & $\mathbf{7}$ & $\mathbf{1 0}$ & $\mathbf{1 0}$ & $\mathbf{9}$ & $\mathbf{6 3 0 0}$ \\
\hline $\begin{array}{l}\text { Penyuluhan kader } \\
\text { dan masyarakat }\end{array}$ & 8 & 6 & 6 & 6 & 1728 \\
$\begin{array}{l}\text { tentang } \\
\text { pembuangan }\end{array}$ & & & & & \\
sampah & 8 & 6 & 6 & 5 & 1440 \\
\hline $\begin{array}{l}\text { Penyuluhan } \\
\begin{array}{l}\text { Kesehatan terkait } \\
\text { penyakit akibat } \\
\text { sampah }\end{array}\end{array}$ & & & & \\
\hline Jumat bersih & 10 & 8 & 8 & 8 & 5120
\end{tabular}

Berdasarkan pemecahan masalah yang terpilih, maka kegiatan yang akan dilakukan adalah pendirian bank sampah, oleh dan untuk masyarakat.

\section{Pengembangan Program (Program Plan Development)}

Selanjutnya dilakukan pengembangan program yang akan dilaksanakan secara sistematis, diantaranya adalah: 
1. Pemberdayaan dan Pengembangan Masyarakat

Dalam melaksanakan program bank sampah, diperlukan adanya pemberdayaan masyarakat untuk berpartisipasi aktif dalam program ini. Oleh karena itu, diinisiasi dan dibentuk suatu komunitas yang terdiri dari masyarakat setempat utamanya dari RW 04/RT 09, Kelurahan Pegirian. Adapun untuk membentuk komunitas tersebut dilakukan beberapa tahapan, diantaranya adalah: Pertama, Musyawarah dengan Masyarakat. Tahap awal yang dilakukan adalah melakukan musyawarah dengan masyarakat setempat yang memiliki pengaruh besar terhadap masyarakat disana seperti ketua RT dan lurah setempat. Dalam musyawarah ini, disampaikan maksud dan tujuan program serta meminta izin merealisasikan program di kawasan tersebut. Selain itu, juga disampaikan teknis kegiatan yaitu berupa sosialisasi langsung ke masyarakat melalui presentasi dan buku pedoman mengenai cara pemilahan sampah, manfaat ekonomis sampah dan penjelasan program.

Kedua, Pelatihan Kader. Pelatihan yang dibuat berupa sosialisasi, diskusi dan pemberian modul sederhana agar dapat menjadi pegangan bagi para pengurus dan pengelola komunitas tersebut. Kader di wilayah RW 04/RT 09, Kelurahan Pegirian sangat aktif dan antusias dalam mengikuti kegiatan pelatihan 'Bank Sampah'. Selain kader PKK, dalam pelatihan kader ini, pihak karang taruna juga turut serta dalam memperkuat inisiasi kegiatan 'Bak Sampah' ini. Dalam kegiatan pelatihan kader ini, terdapat 5 kader PKK dan 8 orang pengurus karang taruna di wilayah RW 04/RT 09.

Ketiga, Penggalangan Komitmen dan Perumusan Materi Pelatihan Bank Sampah. Adapun langkahlangkah dalam tahapan ini dilakukan sebagai berikut: (1) Pembentukan Komitmen dan Pengurus Bank Sampah. Langkah awal yang akan dilakukan adalah menggalang komitmen dari masyarakat sehingga keberlanjutan program bank sampah dapat terjamin dan didukung oleh seluruh masyarakat. Penetapan pengurus bank sampah ditetapkan sebagai kader tetap pada program bank sampah. (2) Menentukan materi pelatihan dan mencari narasumber. Adapun materi yang diberikan kepada masyarakat adalah mengenai pemilah sampah rumah tangga, cara mengelola sampah organik dan sampah anorganik menjadi produk yang bernilai jual tinggi. (3) Pembuatan dan penyebaran poster serta brosur untuk sosialisasi berisi tentang manfaat bank sampah sebagai upaya peningkatan pendapatan keluarga.

2. Pelatihan Program Bank Sampah

Pelatihan Program Bank Sampah bagi kader beserta tokoh masyarakat setempat di RW 04/RT 09, Kelurahan Pegirian. Respon masyarakat sangat baik, ini ditunjukkan dengan 30 orang 


\section{ENGAGEMENT}

Lurnal Pengabdian Kepada Masyarakat

ISSN : 2579-8375 (Print)

ISSN : 2579-8391 (Online)
This work is licensed under a Creative Commons

Attribution-ShareAlike 4.0 International License.

CC BY SA

hadir dalam pelatihan Program Bank Sampah ini. dalam sessi ini masyarakat juga dapat melihat secara langsung demonstrasi alur bank sampah oleh kader yang telah dilatih.

3. Pelaksanaan Program Oleh Masyarakat (Follow up dan Controling)

Pada tahap ini, pelaksanaan program bank sampah akan ditindaklanjuti terkait perkembangan pengurus bank sampah yang telah dibentuk. Dengan adanya ini, diharapkan komunitas yang terbentuk telah mampu melaksanakan program kerja yang telah dirancang bersama. Diharapkan setelah beberapa bulan atau beberapa tahun, kemudian kelurahan Pegirian dapat menciptakan masyarakat yang memiliki kemampuan dan ketrampilan untuk memanfaatkan hasil bank sampah menjadi barang yang bernilai ekonomis.

\section{Implementasi (Implementation) dan Evaluasi (Evaluation)}

Tahap implementasi ini adalah pendirian bank sampah di RW 04/RT09 Kelurahan Pegirian. Berdasarkan analisis masalah sampai dengan tahap plan of action, rincian kegiatan pendirian bank sampah adalah sebagai berikut:

1. Pembentukan Bank Sampah

Bank sampah merupakan salah satu wujud solusi dalam menangani masalah sampah dengan menerapkan prinsip 3R (Reduce, Reuse, Recycle). Melalui bank sampah, penyelesaian masalah sampah tidak hanya berfokus pada petugas kebersihan saja melainkan kepada masyarakat dan pemerintah sekitar. Bank sampah juga merupakan suatu sistem pengelolaan sampah kering secara kolektif yang dapat mendorong peran serta aktif masyarakat di dalamnya. Sistem bank sampah ini akan menampung, memilah, dan menyalurkan sampah bernilai ekonomi pada pasar sehingga masyarakat akan mendapatkan keuntungan ekonomi dari menabung sampah tersebut.

Pelaksanaan bank sampah di Kelurahan Pegirian, Kecamatan Semampir, Kota Surabaya tersebut akan dilakukan secara bertahap sebagai berikut :

a. Koordinasi dan Penggalangan Komitmen

Koordinasi diperlukan untuk menyampaikan tujuan dan mekanisme program bank sampah kepada Lurah dan pejabat terkait, sekaligus menyiapkan target sasaran sebagi kader dan pengurus program. Kegiatan ini sesua dengan aspek implementasi program menurut Teori Dignan, yaitu gain acceptance for the program (persetujuan program) yaitu program ini telah mendapatkan perijinan dari Lurah dan tokok masyarakat setempat, serta specify task and estimate 
resource needs (Tugas dan kebutuhan sumber daya) yaitu terdapat spesifikasi program dan tugas masing-masing sumber daya serta kebutuhan program ${ }^{18}$

Setelah mendapatkan perijinan, dilakukan penggalangan komitmen agar sepakat untuk bekerja sama dalam mendirikan bank sampah. Pembentukan pengurus menjadi momentum awal dari program bank sampah ini. Struktur kepengurusan bank sampah Pegirian adalah sebagai berikut:

\section{Struktur Organisasi}

Penanggungjawab Koordinator RT

Ketua

Sekretaris

Bendahara

\section{Bank Sampah Pegirian} :Khuliyah Candraning Diyanah dan Kepala RT 09/RW04 :Rohimah :Siti Rahayu :Yuyun Wida Ningsih :Zulmaroh

b. Sosialisasi dan Uji Coba

Bulan kedua difokuskan pada kegiatan sosialisasi dan uji coba sistem bank sampah kepada masyarakat Kelurahan Pegirian, Kecamatan Semampir, Kota Surabaya. Pada sosialisasi ini, diberikan pengenalan dan pengetahuan dasar mengenai bank sampah. Wacana yang disampaikan adalah bank sampah merupakan program nasional, penjelasan umum terkait bank sampah, alur pengolahan sampah pada bank sampah, dan lain-lain ${ }^{19}$. Masyarakat ditunjukkan cara melakukan pemilahan sampah organik dan sampah anorganik, untuk kemudian dapat ditabung di bank sampah. Sampah anorganik akan dikumpulkan ke pengepul, kemudian ditimbang dan hasilnya akan dikonversikan kedalam rupiah pada tabungan masyarakat. Tahapan sosialisasi ini juga sesuai dengan aspek implementasi program menurut Teori Dignan, yaitu establish mechanism for program management (menetapkan mekanisme untuk manajemen program). ${ }^{20}$

Dalam kegiatan sosialisai ini, hadir 30 orang peseta (69,77\%) yang merupakan tokoh masyarakat, kader PKK, karang taruna, dan juga perwakilan warga RW 04/RT 09 Kelurahan Pegirian.

18 Yuliandari, Inriza, Nenda Puspita Sari, Rochmad Ardiansyah, and Novanyanti Nur. “Angon Sampah Sebagai Upaya Pemberdayaan Masyarakat Berbasis Potensi Lokal Di Desa Pesucen Melalui Teori Dignan.” Promotif: Jurnal Kesehatan Masyarakat 8, no. 2 (2018): 112-122.

${ }^{19}$ Eka Utami, "Buku Panduan Sistem Bank Sampah Dan 10 Kisah Sukses," Yayasan Unilever Indonesia, Jakarta (2013).

20 Yuliandari, Inriza, Nenda Puspita Sari, Rochmad Ardiansyah, and Novanyanti Nur. "Angon Sampah Sebagai Upaya Pemberdayaan Masyarakat Berbasis Potensi Lokal Di Desa Pesucen Melalui Teori Dignan.” Promotif: Jurnal Kesehatan Masyarakat 8, no. 2 (2018): 112-122

Volume 3, Number 2, November 2019| 256 Pendampingan Masyarakat Bantaran Sungai dalam Pendirian Bank Sampah untuk Meminimalisir Sampah Sungai di Kelurahan Pegirian Kota Surabaya 

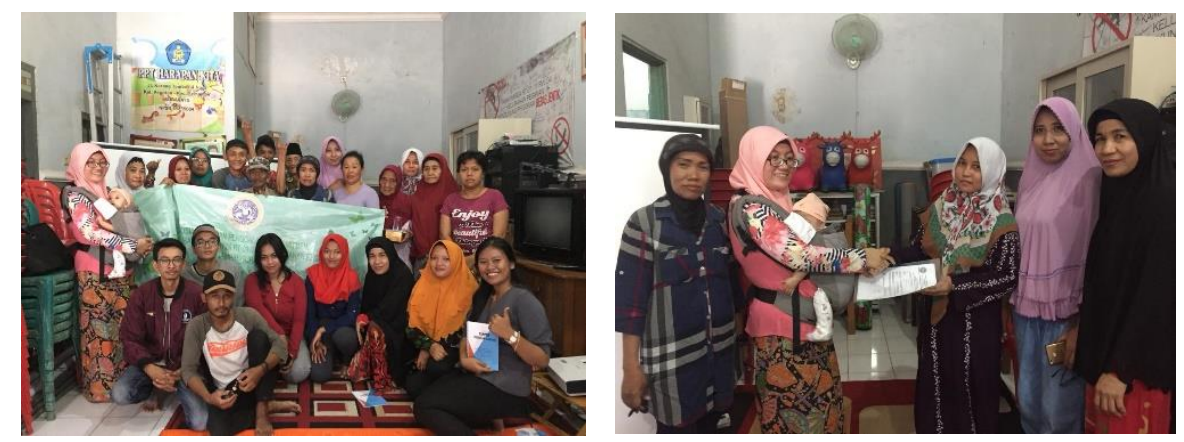

Gambar 3. Sosialisasi dan Penggalangan Komitmen

c. Implementasi Bank Sampah

Pada bulan ketiga dan keempat, masyarakat Kelurahan Pegirian, Kecamatan Semampir, Kota Surabaya mulai melakukan proses penyetoran sampah anorganik kepada pengepul secara rutin sesuai waktu yang telah disepakati dan sesuai dengan batas minimal penyetoran sampah anorganik yang telah disepakati. Segala implementasi bank sampah telah dilaksanakan sepenuhnya oleh masyarakat, yang dikoordinasi oleh kader yaitu pengurus bank sampah. Anggota bank sampah adalah berjumlah 24 orang/55,81\% (dari total jumlah KK di wilayah RW 04/RT 09 yaitu $43 \mathrm{KK}$ ), dengan jumlah pengurus inti sebanyak 5 orang. Jumlah kader keseluruhan berjumlah 13 dengan rincian 5 orang berasal dari kader PKK dan 8 orang karang taruna. Jumlah anggota bank sampah sudah memenuhi target awal yang hanya 50\% dari KK menjadi anggota bank sampah.

Kegiatan pengumpulan sampah sesuai dengan kesepakatan peserta bank sampah dilaksanakan rutin dua minggu sekali yang dimulai dari Bulan Juli. Sampah yang dikumpulkan sesuai jenis yang ditentukan yakni botol plastik, gelas plastik, plastik berwarna, kertas, kardus, kaleng dan besi. Selanjutnya dilakukan penimbangan berdasar masing-masing jenis sampahnya. Setelah diketahui berat sampah yang ditimbang maka selanjutnya dicatat pada buku besar dan buku tabungan masing-masing peserta. Berat sampah yang terkumpul berdasarkan jenisnya dari bulan Juli hingga September pada program bank sampah terdapat pada Tabel 3 di bawah ini:

Tabel 3 Hasil Pengumpulan Sampah Bank Sampah RT09/RW04 Pegirian

\begin{tabular}{cccccccc}
\hline & & \multicolumn{6}{c}{ Berat berdasarkanJenis Sampah (kg) } \\
\cline { 2 - 7 } & $\begin{array}{c}\text { Botol } \\
\text { Plastik }\end{array}$ & $\begin{array}{c}\text { Gelas } \\
\text { Plastik }\end{array}$ & Kardus & Kertas & Kaleng & $\begin{array}{c}\text { Plastik } \\
\text { Berwarna }\end{array}$ \\
\hline 1. & $15 / 07 / 2018$ & 3,3 & 0,5 & 1,5 & 0,5 & 1,8 & -
\end{tabular}


ENGAGEMENT

Lurnal Pengabdian Kepada Masyarakat

ISSN : 2579-8375 (Print)

ISSN : 2579-8391 (Online)
This work is licensed under a Creative Commons Attribution-ShareAlike 4.0 International License. CC BY SA

\begin{tabular}{cccccccc}
2. & $29 / 07 / 2018$ & 7,2 & 0,6 & 7,9 & - & - & 4,3 \\
3. & $05 / 08 / 2018$ & 5,2 & 0,8 & 5,0 & 2,0 & - & 2,0 \\
4. & $19 / 08 / 2018$ & 3,7 & 1,1 & 3,2 & 1,5 & - & 1,7 \\
5. & $02 / 09 / 2018$ & 4,3 & 0,7 & 2,5 & - & - & 2,3 \\
6 & $16 / 09 / 2018$ & 5,2 & 3,2 & 4,1 & 4,7 & - & 3,5 \\
\hline
\end{tabular}

Sampah yang terkumpul selanjutnya dijual ke pengepul dan dana yang terkumpul dikelola pengurus bank sampah dengan perhitungan yang disepakati oleh seluruh anggota bank sampah. Tabungan peserta sesuai dengan kesepakatan dapat diambil satu tahun sekali yakni pada akhir tahun.

Sebagai upaya untuk menunjang kegiatan operasional bank sampah di RT 09/RW 04 Kelurahan Pegirian maka dibangun tempat yang berfungsi sebagai tempat penimbangan dan tempat pengumpulan sampah yang dikumpulkan peserta bank sampah. tempat ini dibangun di atas tanah milik kelurahan atas ijin kepala kelurahan dan Camat setempat. Pembangunan tempat ini dilaksanakan pada bulan Agustus 2018.
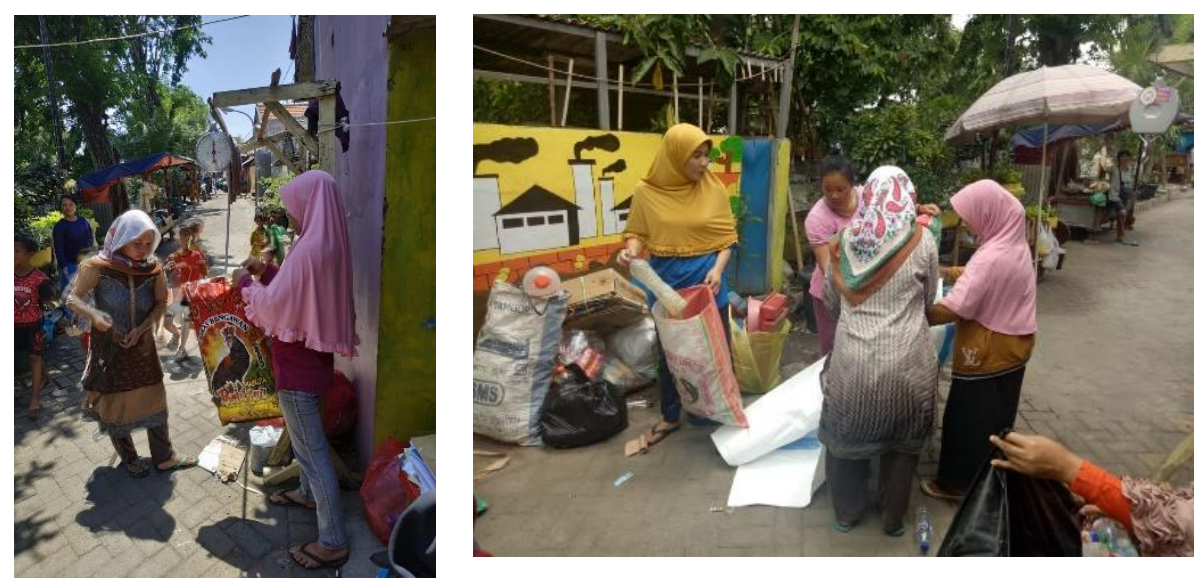

Gambar 4. Proses Penimbangan Sampah

d. Monitoring dan Evaluasi

Salah satu cara untuk monitoring dan evaluasi adalah dengan melakukan pre test - post test untuk melihat tingkat pengetahuan peserta bank sampah mengenai materi yang diberikan. Selain itu juga dilakukan pemantauan sebagai bentuk monitoring yang selanjutnya dilakukan evaluasi sebagai bahan perbaikan bank sampah.

Pre test-post test dilakukan pada saat kegiatan yang bertujuan meningkatkan pengetahuan peserta bank sampah seperti materi bank sampah dan materi pengolahan sampah. Pre test - post test dilaksanakan bertepatan pada saat kegiatan sosialisasi program bank sampah. Hasil pre test - post test menunjukkan peningkatan pengetahuan yang ditunjukkan dengan sebanyak $78 \%$ peserta

Volume 3, Number 2, November 2019| 258

Pendampingan Masyarakat Bantaran Sungai dalam Pendirian Bank Sampah untuk Meminimalisir Sampah Sungai di Kelurahan Pegirian Kota Surabaya 
mendapat nilai lebih baik setelah dilakukan pemberian materi mengenai sampah dan juga bank sampah.

Monitoring dan evaluasi juga dilakukan pada setiap kegiatan pengumpulan dan penimbangan sampah. Hingga bulan September, penimbangan telah dilakukan sebanyak enam kali. Jumlah peserta yang datang untuk menimbang sampah dan berat seluruh sampah yang berhasil dikumpulkan dicatat secara periodik pada buku besar. Hasil pencatatan diketahui bahwa pada delapan kali penimbangan masih belum seluruh peserta datang rutin untuk menimbang sampah. Berat sampah yang dikumpulkan pun juga masih naik turun, dimana pada penimbangan pertama yang memiliki jumlah paling banyak. Kondisi ini perlu menjadi perhatian semua pihak, agar berbagai kendala dalam implementasi program bank sampah dapat diselesaikan dengan baik.

Rencana tindak lanjut dari program bank sampah ini adalah pelatihan composting dengan Takakura (kompos tingkat keluarga) dan juga pelatihan crafting. Semua program ini selain untuk mengurangi timbulan sampah, menciptakan lingkungan yang bersih ${ }^{21}$, juga merupakan upaya dalam peningkatan penghasilan warga masyarakat.

\section{Kesimpulan}

Program Kemitraan kepada Masyarakat (PKM) yang diadakan di Kelurahan Pegirian, Kecamatan Semampir, Kota Surabaya telah berhasil menjalankan bank sampah. Proses pelaksanaan bank sampah berpedoman pada Teori Dignan, yakni dimulai dari analisis situasi masyarakat, penentuan target, implementasi program oleh masyarakat, hingga monitoring dan evaluasi. Inisiasi pendirian Bank Sampah di Kelurahan Pegirian dapat dikatakan berhasil dengan indikator anggota bank sampah yang mencapai 55,81\% (24/43) dari total kepala keluarga yang ada di wilayah RW04/RT09 Kelurahan Pegirian, selain itu hasil pre-post test menunjukkan peningkatan pengetahuan yang ditunjukkan dengan sebanyak $78 \%$ peserta mendapat nilai lebih baik setelah dilakukan pemberian materi mengenai sampah dan juga bank sampah.

Beberapa saran berikut dapat mengoptimalkan program bank sampah di Kelurahan Pegirian: (1) Meningkatkan sosialisasi melalui kader maupun media offline, seperti poster dan brosur. Melalui penyebaran informasi tentang bank sampah, maka masyarakat akan menyadari manfaat dari bank sampah dan tertarik untuk menabungkan sampahnya; (2) Melakukan pengembangan pada program bank sampah dengan bekerjasama pada instansi lintas sektor, untuk mengadakan

${ }^{21}$ Abdul Rozak, "Peran Bank Sampah Warga Peduli Lingkungan (WPL) Dalam Pemberdayaan Perekonomian Nasabah" (2014).

Volume 3, Number 2, November 2019| 259

Pendampingan Masyarakat Bantaran Sungai dalam Pendirian Bank Sampah untuk Meminimalisir Sampah Sungai di Kelurahan Pegirian Kota Surabaya 


\section{ENGAGEMENT}

Lurnal Pengabdian Kepada Masyarakat

ISSN : 2579-8375 (Print)

ISSN : 2579-8391 (Online)
This work is licensed under a Creative Commons Attribution-ShareAlike 4.0 International License. CC BY SA

pelatihan baru secara rutin terkait pengolahan hasil bank sampah. Masyarakat diajarkan materi baru tentang cara mengolah sampah menjadi produk yang bernilai jual tinggi, sehingga masyarakat terus tertarik untuk datang ke bank sampah; (3) Mengembangkan peran kader agar mengajak masyarakat untuk memilih menabungkan sampahnya di bank sampah. Jika masyarakat tau manfaat dari mengikuti bank sampah, maka masyarakat tidak akan menukarkan sampahnya ke pemulung yang datang. Kegiatan yang bervariasi setiap diadakannya bank sampah, juga bisa menjadi sarana untuk menarik minat masyarakat, misal dibarengi dengan koperasi atau arisan sampah.

\section{Daftar Pustaka}

Bastian, Ardi. "Perencanaan Program Promosi Kesehatan dalam Penanggulangan Hiv dan Aids pada Ibu Rumah Tangga di Kota Kediri Menggunakan Kerangka Teori Dignan dan Carr." Universitas Airlangga, 2017.

BBC News Indonesia. “Ke Mana Perginya 1.000 Ton Sampah Di Surabaya?” Last modified 2018. Accessed November 1, 2019. https://www.bbc.com/indonesia/majalah-43939576.

BPS Kota Surabaya. Kecamatan Semampir Dalam Angka 2016. Kota Surabaya, 2016. https://surabayakota.bps.go.id/publication/2016/07/29/441878badba3c8525b717c0d/kec amatan-semampir-dalam-angka-2016.

BPS Kota Surabaya. Kecamatan Semampir Dalam Angka 2018. Surabaya, 2018. https://surabayakota.bps.go.id/publication/2018/09/26/90ec03cb6809df424f7e6ee8/keca matan-semampir-dalam-angka-2018.html.

Christiani, Charis, Pratiwi Tedjo, and Bambang Martono. "Analisis Dampak Kepadatan Penduduk Terhadap Kualitas Hidup Masyarakat Provinsi Jawa Tengah.” Serat Acitya 3, no. 1 (2014): 102.

Dignan, MB, and PA Carr. Program Planning for Health Education and Promotion, 2nd Ed. Philadelphia: Lea \& Febiger, 1992.

Fathurrohman, Amang, M Dayat, Zainul Ahwan, Daim Abror, Lukman Hakim, Syukur Apriwiyanto, Imam Syafi'i, Fafit Rahmat Aji, and Mulyono. Wobisono. "Implementasi Manajemen Bank Sampah IT Pada Komunitas Bank Sampah Berbasis Masyarakat, Pemuda, Dan Sekolah Di Kabupaten Pasuruan.” Engagement: Jurnal Pengabdian Kepada Masyarakat 2, no. 2 (2018): 154-167. http://engagement.fkdp.or.id/index.php/engagement/article/view/35.

Hidup, Menteri Lingkungan. Peraturan Menteri Lingkungan Hidup No 13 Tabun 2012 Tentang Pedoman Pelaksanaan Reduce, Reuse Dan Recycle Melalui Bank Sampah. Jakarta, 2012. Accessed November 1, 2019. http://sipsn.menlhk.go.id/?q=content/peraturan-menteri-lh-no-13-tahun-2012.

muslimah, muslimah muslimah. "Dampak Pencemaran Tanah dan Langkah Pencegahan." Jurnal Penelitian Agrisamudra 2, no. 1 (2015): 11-20.

Nuria, Nuria, and Yuly Sulistyorini. “Analisis Kesehatan Masyarakat Berdasarkan Ruang Lingkup

Volume 3, Number 2, November 2019| 260

Pendampingan Masyarakat Bantaran Sungai dalam Pendirian Bank Sampah untuk Meminimalisir Sampah

Sungai di Kelurahan Pegirian Kota Surabaya

Khuliyah Candraning Diyanah, Aditya Sukma Pawitra, Ni Luh Putu Arum Puspitaning Ati,

Mohammad Bastian, Ika Septyaningsih, Rahmat Adi Prasetyo 
ENGAGEMENT

Lurnal Pengabdian Kepada Masyarakat

ISSN : 2579-8375 (Print)

ISSN : 2579-8391 (Online)
This work is licensed under a Creative Commons Attribution-ShareAlike 4.0 International License. CC BY SA

Kependudukan dan Ketenagakerjaan di Kelurahan Pegirian Kecamatan Semampir Kota Surabaya." Jurnal Biometrika dan Kependudukan 7, no. 2 (2019): 131-140.

Purbasari, Nurul. "Pemberdayaan Masyarakat Melalui Kegiatan Daur Ulang Sampah Plastik (Studi Kasus pada Komunitas Bank Sampah Poklili Perumahan Griya Lembah Depok Kecamatan Sukmajaya Kota Depok)." UIN Syarif Hidayatullah Jakarta, 2014.

Rozak, Abdul. "Peran Bank Sampah Warga Peduli Lingkungan (WPL) dalam Pemberdayaan Perekonomian Nasabah" (2014).

Utami, Eka. "Buku Panduan Sistem Bank Sampah Dan 10 Kisah Sukses." Yayasan Unilever Indonesia, Jakarta (2013).

Yuliandari, Inriza, Nenda Puspita Sari, Rochmad Ardiansyah, and Novanyanti Nur. "Angon Sampah Sebagai Upaya Pemberdayaan Masyarakat Berbasis Potensi Lokal Di Desa Pesucen Melalui Teori Dignan.” Promotif: Jurnal Kesehatan Masyarakat 8, no. 2 (2018): 112-122.

Volume 3, Number 2, November 2019 | 261 Pendampingan Masyarakat Bantaran Sungai dalam Pendirian Bank Sampah untuk Meminimalisir Sampah Sungai di Kelurahan Pegirian Kota Surabaya 